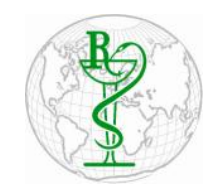

INDO GLOBAL JOURNAL OF

PHARMACEUTICAL SCIENCES

ISSN 2249- 1023

\title{
Study of Essential Oil of Few Species with High Antioxidant Potential
}

\author{
Deepshikha Gupta ${ }^{*}$, Prabhkeen Kaur \\ ${ }^{1}$ Department of Chemistry, Amity Institute of Applied Sciences, Amity University, Sector-125, Noida-201303, India
}

\begin{abstract}
Address for Correspondance Deepshikha Gupta, dgupta2@amity.e $\underline{\mathrm{du}}$

ABSTRACT: Our main objective is to analyze essential oil extracted from clove buds, cinnamon bark and dill seeds. The essential oil will be tested for antibacterial activity and their major constituents will be analyzed by GCMS. The essential oil fraction was extracted by Clevenger's apparatus. Their antibacterial activity was measured against gram positive and gram negative bacterial strains by agar well method. The oil samples were subjected to GCMS analysis for identification of their active constituents. Cinnamon and clove oils showed good antibacterial activity and can be used as protective agents. GCMS studies identified the presence of

Keywords eugenol, eugenyl acetate, $\alpha$-cadinol in clove oil;cinnamaldehyde, eugenol, trans-caryophyllene, caryophyllene oxide and torreyol in cinnamon and D-limonene, D-carvone, apiol were found to be present in dill essential oil. Cinnamon oil showed highest antibacterial activity among the three food supplements. (c) 2015 iGlobal Research and Publishing Foundation. All rights reserved.

Cinnamon;
\end{abstract}

Clove; Dill;

Antibacterial; Antioxidant Activity.

\section{INTRODUCTION}

The word essential oil is given to the plant oil because it contains the essence of the fragrance of the plant from which it has been obtained. The essential oil is basically a concentrated hydrophobic liquid which contains volatile aromatic compounds. The essential oils are mainly obtained by steam distillation. The use of essential oils could be seen in the products that we use in our daily life. This includes incense sticks, perfume, cosmetics, soaps etc.

Interest in essential oils has revived in recent decades with the popularity of aromatherapy that claims that essential oils and other aromatic compounds have curative effects and can be used for the purpose of altering one's mood, cognitive, psychological or physical wellbeing [1]. Here we have analyzed essential oils extracted from three spices which are known to have high antioxidant potential. Clove oil is obtained from Clove bud (Syzygium aromaticum). It has a sweet, spicy fragrance that is stimulating and revitalizing. The clove oil is a natural antiseptic as well as analgesic. It contains eugenol which is the main ingredient used in dentistry. It is also used in flavouring of some medicines. The biggest manufacturers of clove oil are Madagascar and Indonesia [3]If taken in large amount of clove oil may cause nausea, vomiting, abdominal pain, rapid heartbeat, increased breathing, intestinal bleeding etc [3].

Cinnamon oil is obtained from the bark of Cinnamon (Cinnamomum zeylanicum). Cinnamon is now being used all over the world for the treatment of a variety of health disorders including respiratory problems, skin infections, blood impurity, menstrual problems, and various heart disorders [4]. It is effective on treating external as well as internal infections due to antimicrobial action. Due to its sweet smell cinnamon is also used as spice, in chewing gums and perfumery.

Dill (Anethum sowa) belongs to Apiaceae family and its oil is obtained from its seeds. The basic components of 


\section{Indo Global Journal of Pharmaceutical Sciences, 2015; 5(3): 216-224}

dill essential oil are D-Carvone, Dillapiol, Eugenol, Limonene, Terpinene and Myristicin. Since ancient times dill seeds have been associated with magical healing powers [5]. Dill oil promotes digestion by stimulating the secretion of digestive juices like gastric juices, acid and bile in the stomach. It is also antispasmodic, carminative, stomachic, antipyretic and galactogogue.

In this paper we have analyzed theGCMS studies of volatile oils of the selected spice having good antioxidant potential [6] samples and evaluated their antimicrobial potential by agar well method. The GCMS studies would reveal the important compounds responsible for their high antioxidant potential and antimicrobial activity.

\section{MATERIALS \& METHODS}

\section{Chemicals and Materials}

Distilled water used was twice deionized before use. Agar-agar, Nutrient broth, DMSO, Streptomycin, methanol, Clevenger Apparatus (Borosil model 3450), Soxhlet apparatus (Borosil model 3840), Laminarairflow bench, Incubator, Autoclave, Shimadzu UV 1800 spectrophotometer, DPPH (sigma), Ascorbic acid (AR grade).

\section{Sample extraction}

The cinnamon bark, clove buds and dill seeds were procured from local market. The samples were dried in shade and grounded by the help of food processor and then hydro distilled using Clevenger's Apparatus for one hour to yield the colourless to pale yellow and highly fragrant essential oil which was dried over anhydrous sodium sulphate and stored at $4^{\circ} \mathrm{C}$ before use. The methanolic extracts were obtained by soxhlet extraction method using methanol as a solvent. The methanolic extracts obtained were then concentrated using rotary vacuum evaporator. The extracts were finally lyophilized to obtain a dark coloured powder which was stored at $5^{\circ} \mathrm{C}$ until used. The extracts were dissolved in methanol to obtain w/v solution to verify the high antioxidant potential of spices and antibacterial activity was evaluated.

\section{Antibacterial Studies}

The purpose to carry out the antibacterial study is to determine the sensitivity of the volatile oil and methanolic extracts of clove, cinnamon and dill towards pathogenic/non-pathogenic strains of bacteria so as to check the potential use of their specific compound in development of antibacterial agents.

Gram positive bacteria: Bacillus subtilis, Micrococcus luteus, Staphylococcous aureus

Gram negative bacteria: Pseudomonas aeruginosa, Escherichia coli

\section{Procedure}

The method used was agar well method. Bacterial inoculum was prepared up to $0.5 \mathrm{McFarland}$ turbidity standards. For antibacterial activity, inoculation of agar plates was done by pouring $20 \mu \mathrm{L}$ of the culture medium and spreading uniformly by the sterilized spreader or sterile inoculation loop. Wells of appropriate sizes $(6 \mathrm{~mm}$ diameter) were cut using cork borer. $20 \mu \mathrm{L}$ of the prepared dilutions of the spice extracts were poured in the center of well vertically by a micropipette along with one well of positive control (antibiotic streptomycin). After loading the samples, the plates were incubated at $37{ }^{\circ} \mathrm{C}$ for 18-24 $\mathrm{h}$ for antibacterial study. Zone of Inhibition (ZOI) were observed by measuring the diameter of the clear zone around the wells using zone scale reader. The plates were studied in triplicates. The various dilutions (Pure, 1:1, and 1:3 concentrations) of volatile oil of clove, cinnamon and dill seeds were made with DMSO. The methanol extracts of the samples were lyophilized to obtain solid powders which werethen dissolved in methanol to get w/v concentrations of $1,5,10,50 \& 100$ $\mathrm{mg} / \mathrm{mL}$.

\section{GCMS Conditions}

The GCMS instrument used was Thermo Scientific TRACE Ultra Gas Chromatograph. Column used was Alltech ECONO CAP EC-5(30m X $0.25 \mathrm{~mm}, 0.25 \mu \mathrm{m})$. Carrier gas used was Helium with flow rate of $1 \mathrm{ml} / \mathrm{min}$. Oven initial temperature was $150{ }^{\circ} \mathrm{C}$ with 1 minute hold Temperature programming of $10{ }^{\circ} \mathrm{C}$ increase up to $200{ }^{\circ} \mathrm{C}$ with $2 \mathrm{~min}$ hold then $5{ }^{\circ} \mathrm{C}$ increase up to final Temperature of $280{ }^{\circ} \mathrm{C}, 5 \mathrm{~min}$ hold was done. Injector temperature $200{ }^{\circ} \mathrm{C}$ and temperature of interface was 300 ${ }^{\circ} \mathrm{C}$; Injection Volume was $1 \mu \mathrm{L}$. Mass spectroscopic condition was full scan mode with electron impact ionization and source temperature at $200^{\circ} \mathrm{C}$. 
Indo Global Journal of Pharmaceutical Sciences, 2015; 5(3): 216-224

\section{RESULTS \& DISCUSSION}

The GCMS results obtained for Dill essential oil sample

is given in Figure 1.

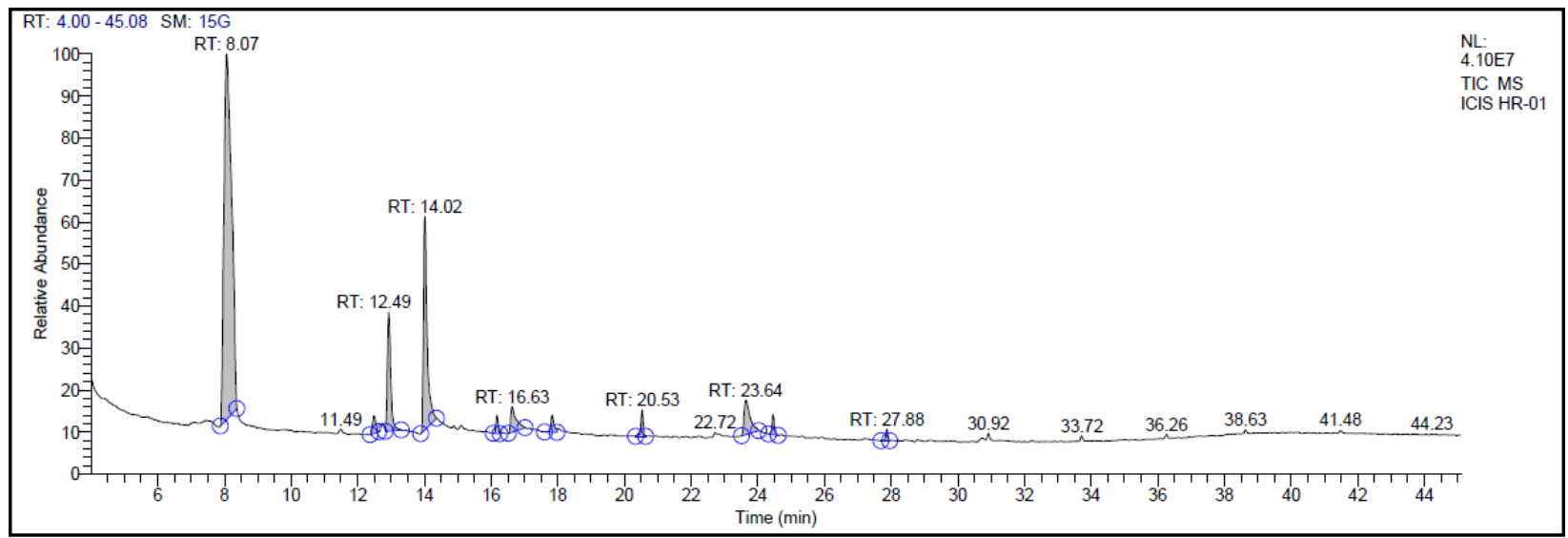

Figure 1: Dill essential oil GCMS peaks

Table 1: The identified compounds in Dill essential oil based on Mass fragmentation peaks and library search data

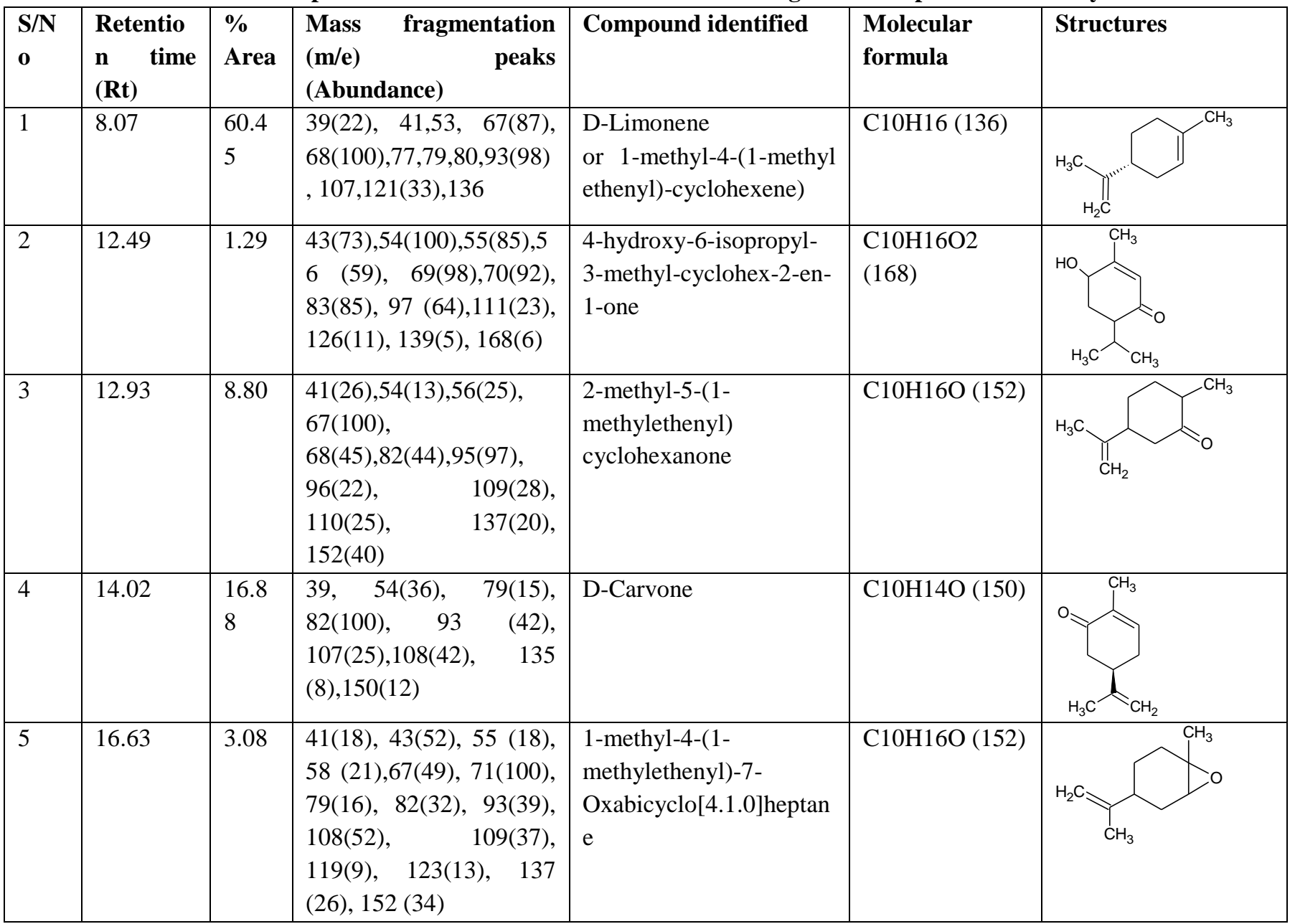


Indo Global Journal of Pharmaceutical Sciences, 2015; 5(3): 216-224

\begin{tabular}{|c|c|c|c|c|c|c|}
\hline 6 & 17.83 & 1.22 & $\begin{array}{lll}41(56), & 43(62), & 55(87), \\
56(65), & 57(72), & 69(97), \\
70(83), & 83(100), \\
111(40), & 126(16), \\
139(4), & 153(30), & 168(4)\end{array}$ & $\begin{array}{l}\text { 2-hydroxy-3-methyl-6- } \\
\text { isopropyl cyclohex-2-en- } \\
\text { 1-one }\end{array}$ & $\begin{array}{l}\text { C10H16O2 } \\
(168)\end{array}$ & 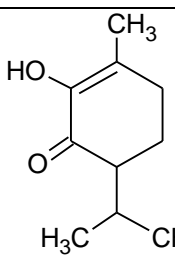 \\
\hline 7 & 23.64 & 4.53 & $\begin{array}{l}39,65(6), 77(15), 91, \\
121(20), \\
149(30), 177(48), 191 \\
(8), 207(28), 222(100), \\
223(15)\end{array}$ & Apiol & $\begin{array}{l}\mathrm{C} 12 \mathrm{H} 14 \mathrm{O} 4(222 \\
)\end{array}$ & \\
\hline
\end{tabular}

The results of GCMS analysis of dill essential oil (Figure 1) showed the presence of many peaks of which seven were identified (Table 1) by their mass fragmentation pattern matching the library search data. The maximum concentration was of limonene followed by carvone, a hydroxyl ketone and apiol. The isomer of the hydroxyl ketone also appeared at Rt 17.83 in small concentration with $\mathrm{M}+$.at 168. A bicylooxirane compound also appeared at Rt 16.63 with M+. at 152. Babri et al [7] analysed the essential oil of dill growing in provinces of Pakistan and identified the presence of R-(-)-carvone (38.899\%), apiol $(30.812 \%)$, limonene(15.938\%) and trans-(+)dihydrocarvone $(10.999 \%)$ as the main components. They found the essential oil to be toxic to Periplaneta americana L., Musca domestica L. and Tribolium castaneum. The bicyclo compound and the isomeric hydroxyl ketones were identified and reported in our sample of dill for the first time.

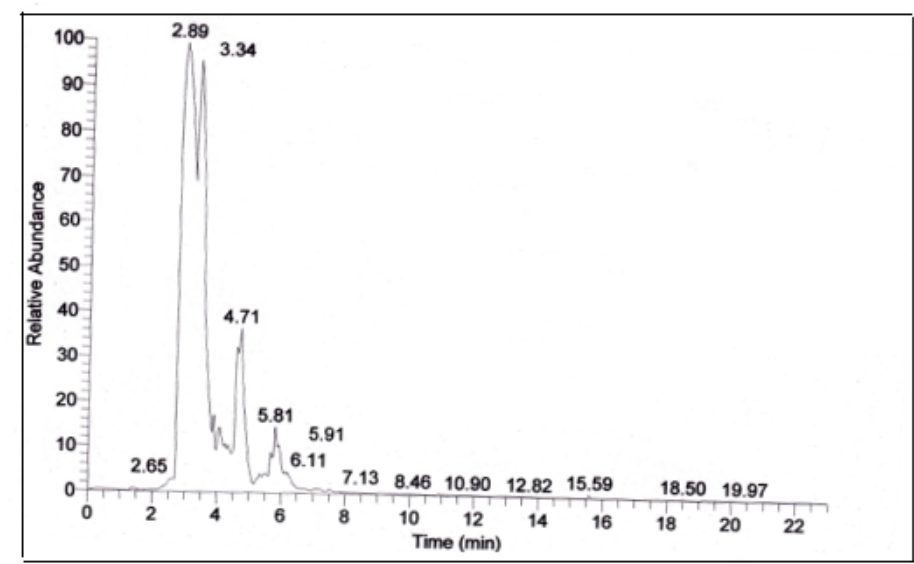

Figure 2: GCMS peaks of essential oil of Clove bud

Table 2: The identified compounds in Clove essential oil based on Mass fragmentation peaks and library search data

\begin{tabular}{|c|c|c|c|c|c|c|}
\hline S/No & $\begin{array}{l}\text { Retention } \\
\text { time (Rt) }\end{array}$ & $\begin{array}{l}\% \\
\text { Area }\end{array}$ & $\begin{array}{l}\text { Mass fragmentation }(\mathbf{m} / \mathbf{e}) \\
\text { peaks (Abundance) }\end{array}$ & $\begin{array}{l}\text { Compound } \\
\text { identified }\end{array}$ & $\begin{array}{l}\text { Molecular } \\
\text { formula }\end{array}$ & Structures \\
\hline 1 & 2.89 & 31.45 & $\begin{array}{l}\text { 49(20),51(54),77(60), } \\
78(48), 103(66), 131(100), 132(70), \\
133(15)\end{array}$ & Cinnamaldehyde & C9H8O(132) & (3-phenyl \\
\hline 2 & 3.34 & 25.78 & $\begin{array}{l}77(68), 91(26), 103(80), \\
131(100), 149(38), \\
164(80), 165(14), 166(<5)\end{array}$ & Eugenol & C10H12O2(164) & $\begin{array}{l}\text { 2-methoxy-4-(2- } \\
\text { propenyl) phenol }\end{array}$ \\
\hline
\end{tabular}


Indo Global Journal of Pharmaceutical Sciences, 2015; 5(3): 216-224

\begin{tabular}{|c|c|c|c|c|c|c|}
\hline 3 & 4.71 & 17.23 & $\begin{array}{l}\text { 65(8),77(16),91(25), } \\
\text { 131(24), 149(34), } \\
164(100), 206(15), 207(<5)\end{array}$ & Eugenyl acetate & $\mathrm{C} 12 \mathrm{H} 14 \mathrm{O} 3(206)$ & 2-methoxy-4-(2- \\
\hline 4 & 5.81 & 8.79 & $\begin{array}{l}55(22), 77(18), 79(20), \\
81(14), 91(30), 93(32), \\
95(48), 105(55), 119(58), \\
121(55), 134(10), 161(100) \\
189(12), \quad 204(60), 205(10), \\
222(<5)\end{array}$ & Tau-Cadinol & $\mathrm{C} 15 \mathrm{H} 26 \mathrm{O}(222)$ & $\mathrm{H}_{3} \mathrm{C} \stackrel{\grave{\overline{\mathrm{H}}}}{\mathrm{CH}_{3}}$ \\
\hline
\end{tabular}

The GC spectra of essential oil of clove and cinnamon are shown in figure 2 and figure 3 respectively. The peakswere identified based on fragmentation pattern as shown in table 2 and table 3. The main constituents of clove essential oil identified were found to contain cinnamaldehyde, eugenol, eugenyl acetate and $\tau$-cadinol. Prashar et al found that Clove oil was was highly cytotoxic at concentrations as low as $0.03 \%(\mathrm{v} / \mathrm{v})$ with up to $73 \%$ of this effect attributable to eugenol [8]. In a review on Eugenia caryophyllata (Syzygium aromaticum) by Chaieb et al the major class of compounds found in clove were phenylpropanoids such as carvacrol, thymol, eugenol and cinnamaldehyde [9]. The cinnamon essential oil was found to contain trans-Cinnamaldehyde, 2methoxy-3(2-propenyl) phenol, trans Caryophyllene, acetoeugenol, caryophyllene oxide and Torreyol.

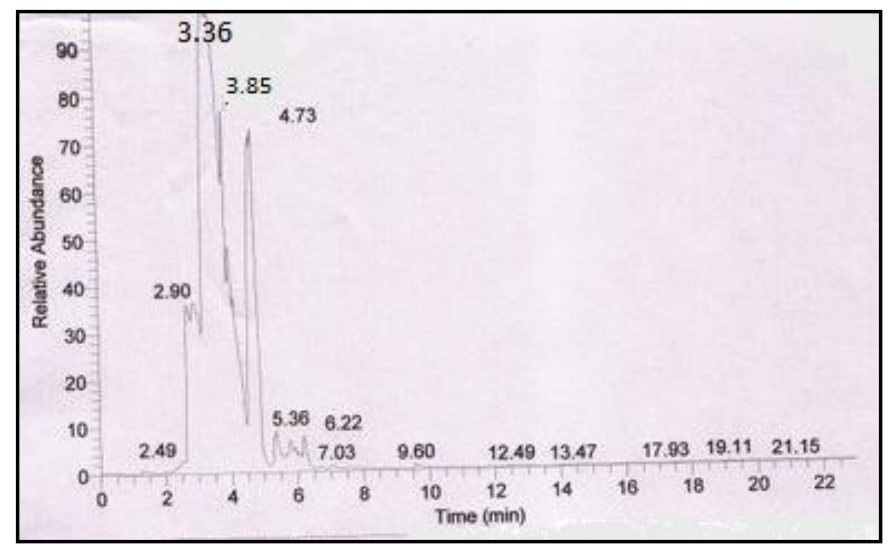

Figure 3: GCMS peaks of essential oil of cinnamon bark 
Indo Global Journal of Pharmaceutical Sciences, 2015; 5(3): 216-224

Table 3: The identified compounds in Cinnamon essential oil based on Mass fragmentation peaks and library search data

\begin{tabular}{|c|c|c|c|c|c|c|}
\hline S/No & $\begin{array}{l}\text { Retention } \\
\text { time }(\mathbf{R t})\end{array}$ & $\begin{array}{l}\% \\
\text { Area }\end{array}$ & $\begin{array}{l}\text { Mass fragmentation }(\mathrm{m} / \mathrm{e}) \\
\text { peaks (Abundance) }\end{array}$ & $\begin{array}{l}\text { Compound } \\
\text { identified }\end{array}$ & $\begin{array}{l}\text { Molecular } \\
\text { formula }\end{array}$ & Structures \\
\hline 1 & 2.90 & 12.62 & $\begin{array}{l}51(48), 65 \\
(\mathrm{C} 5 \mathrm{H} 5)[15], 77(\mathrm{C} 6 \mathrm{H} 5)[62], \\
78(\mathrm{C} 6 \mathrm{H} 6)[56], 103(\mathrm{M}+-\mathrm{H}-\mathrm{CO}) \\
{[74], \quad 104(\mathrm{M}+\mathrm{CO})[70], \quad 131} \\
(\mathrm{M}+-\mathrm{H})[100], \quad 132(\mathrm{M}+)[76], \\
133(\mathrm{M}++1)[15]\end{array}$ & $\begin{array}{l}\text { Trans- } \\
\text { Cinnamaldehyde }\end{array}$ & C9H8O (132) & \\
\hline 2 & 3.36 & 39.39 & $\begin{array}{l}\begin{array}{l}55(27), \\
77(\mathrm{C} 6 \mathrm{H} 5)[38], \\
91(\mathrm{C} 6 \mathrm{H} 5 \mathrm{CH} 2+)[28], \\
103(34), 104(22), \\
131(28), 137(\mathrm{M}+-\mathrm{C} 2 \mathrm{H} 3)[21], \\
149(\mathrm{M}+-\mathrm{CH} 3) \\
164(\mathrm{M}+)[100]\end{array}\end{array}$ & $\begin{array}{l}\text { 2-methoxy-3-(2- } \\
\text { propenyl)phenol }\end{array}$ & $\begin{array}{l}\mathrm{C} 10 \mathrm{H} 12 \mathrm{O} 2 \\
(164)\end{array}$ & \\
\hline 3 & 3.85 & 28.26 & 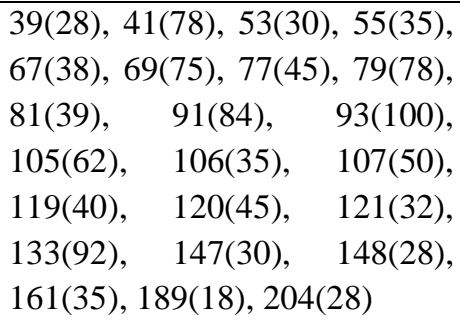 & $\begin{array}{l}\text { Trans } \\
\text { Caryophyllene }\end{array}$ & C15H24 (204) & \\
\hline 4 & 4.73 & 15.23 & $\begin{array}{l}65(8), 77(16), 91(25), \\
131(24), \quad 149(34), \\
164(100), 206(15), 207(<5)\end{array}$ & Acetoeugenol & $\begin{array}{l}\text { C12H14O3 } \\
(206)\end{array}$ & \\
\hline 5 & 5.36 & 2.45 & 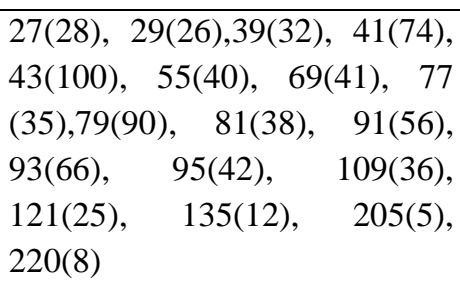 & $\begin{array}{l}\text { Caryophyllene } \\
\text { oxide }\end{array}$ & $\begin{array}{l}\mathrm{C} 15 \mathrm{H} 24 \mathrm{O} \\
(220)\end{array}$ & \\
\hline 6 & 5.79 & 2.05 & $\begin{array}{lll}55(40), & 67(43), 69(50), & 78(40), \\
79(58), & 80(46), 91(72), & 92(60), \\
93(62), & 105(78), & 119(78), \\
136(90), & 161(100), & 162(30), \\
189(14), & 204(60), & 205(15), \\
222(<5) & & \end{array}$ & $\begin{array}{l}\text { Torreyol or } \delta- \\
\text { Cadinol }\end{array}$ & $\begin{array}{l}\text { C15H26O } \\
(222)\end{array}$ & \\
\hline
\end{tabular}


Indo Global Journal of Pharmaceutical Sciences, 2015; 5(3): 216-224

Antibacterial Activity

Antibacterial study of dilutions of volatile oil of samples

Table 4: Antibacterial activity of the three essential oils against selected bacterial strains

\begin{tabular}{|l|l|l|l|l|l|l|l|l|l|}
\hline $\begin{array}{l}\text { Bacterial } \\
\text { Stains }\end{array}$ & $\begin{array}{l}\text { Strain } \\
\text { number }\end{array}$ & $\begin{array}{l}\text { Dill } \\
\text { ZOI } \\
\text { in } \\
\mathbf{c m}\end{array}$ & $\begin{array}{l}\text { Dill } \\
\text { ZOI } \\
\text { in cm }\end{array}$ & $\begin{array}{l}\text { Dill } \\
\text { ZOI in } \\
\mathbf{c m}\end{array}$ & $\begin{array}{l}\text { Cinnamon } \\
\text { ZOI in cm }\end{array}$ & $\begin{array}{l}\text { Clove ZOI in } \\
\mathbf{c m}\end{array}$ & $\begin{array}{l}\text { Clove } \\
\text { ZOI in } \\
\mathbf{c m}\end{array}$ & $\begin{array}{l}\text { Clove } \\
\text { ZOI in } \\
\mathbf{c m}\end{array}$ & $\begin{array}{l}\text { Streptomycin } \\
\text { ZOI in cm }\end{array}$ \\
\hline Concentration & & $(1: 3)$ & $(1: 1)$ & (Pure) & $(1: 3)$ & $(1: 3)$ & $(1: 1)$ & $($ Pure $)$ & $(1 \mathrm{mg} / \mathrm{ml})$ \\
\hline $\begin{array}{l}\text { Bacillus } \\
\text { subtilis }\end{array}$ & MTCC 121 & - & 0.9 & 1.3 & 1.6 & 1.2 & $1.4-1.8$ & 2.2 & 1.0 \\
\hline $\begin{array}{l}\text { Micrococcus } \\
\text { luteus }\end{array}$ & MTCC 106 & - & 1.0 & 1.5 & 2.8 & 1.2 & $1.7-2.0$ & 2.2 & $3.0-3.3$ \\
\hline $\begin{array}{l}\text { Pseudomonas } \\
\text { aerugenosa }\end{array}$ & MTCC1934 & - & - & - & 1.4 & - & - & - & $1.1-1.2$ \\
\hline $\begin{array}{l}\text { Escherichia } \\
\text { coli }\end{array}$ & MTCC1610 & - & $\begin{array}{l}0.9- \\
1.1\end{array}$ & 1.5 & 1.9 & 1.0 & 1.2 & 1.4 & 2 \\
\hline
\end{tabular}

ZOI-Zone of Inhibition in cm; -: No Activity

Antibacterial Activity of methanol extract of samples

Table 5: Antibacterial activity of the methanol extracts of the three samples against selected bacterial strains

\begin{tabular}{|c|c|c|c|c|c|c|c|c|}
\hline Bacterial Strains & $\begin{array}{l}\text { Strain } \\
\text { number }\end{array}$ & $\begin{array}{l}\text { Dill } \\
\mathrm{ZOI} \text { in } \\
\mathrm{cm}\end{array}$ & $\begin{array}{l}\text { Dill } \\
\mathrm{ZOI} \text { in } \\
\mathrm{cm}\end{array}$ & $\begin{array}{l}\text { Cinnamon } \\
\text { ZOI in cm }\end{array}$ & $\begin{array}{l}\text { Cinnamon } \\
\text { ZOI in cm }\end{array}$ & $\begin{array}{l}\text { Clove } \\
\mathrm{ZOI} \text { in } \\
\mathrm{cm}\end{array}$ & $\begin{array}{l}\text { Clove } \\
\mathrm{ZOI} \text { in } \\
\mathrm{cm}\end{array}$ & $\begin{array}{l}\text { Streptomycin } \\
\text { ZOI in cm }\end{array}$ \\
\hline Concentration & & $\begin{array}{l}50 \\
\mathrm{mg} / \mathrm{ml}\end{array}$ & $\begin{array}{l}100 \\
\mathrm{mg} / \mathrm{ml}\end{array}$ & $50 \mathrm{mg} / \mathrm{ml}$ & $100 \mathrm{mg} / \mathrm{ml}$ & $50 \mathrm{mg} / \mathrm{ml}$ & $\begin{array}{l}100 \\
\mathrm{mg} / \mathrm{ml}\end{array}$ & $(1 \mathrm{mg} / \mathrm{ml})$ \\
\hline Bacillus subtilis & MTCC 121 & - & - & - & 0.7 & 0.8 & 1.2 & 1.8 \\
\hline $\begin{array}{l}\text { Micrococcus } \\
\text { luteus }\end{array}$ & MTCC 106 & - & - & - & - & 1.4 & 1.6 & 2.0 \\
\hline $\begin{array}{l}\text { Pseudomonas } \\
\text { aerugenosa }\end{array}$ & MTCC1934 & - & - & - & - & - & - & 2.0 \\
\hline Escherichia coli & MTCC1610 & - & - & 0.9 & 1.7 & 1.1 & 1.3 & 2.3 \\
\hline $\begin{array}{l}\text { Staphylococcos } \\
\text { aureus }\end{array}$ & $\begin{array}{l}\text { ATCC } \\
25923\end{array}$ & - & 1.2 & - & - & $1.3 \pm 0.2$ & 1.7 & 2.8 \\
\hline
\end{tabular}

ZOI-Zone of Inhibition in cm; -: No Activity

The results obtained on evaluation of antibacterial activity of the three essential oils are tabulated in Table 4. Among the three essential oils, cinnamon oil showed significant antibacterial effect at a lower dose concentration of (1:3) against all the bacterial strains tested and also, showed significant activity against Pseudomonas while other samples did not show any activity even in pure undiluted form against Pseudomonas. Activity shown by Dill oil was mild and insignificant. Naveed et at [10] have analysed the effect of four Pakistani spices cumin (Cитіпит cyminum), cinnamon (Cinnamomum verum), cardamom (Amomum subulatum) and clove (Syzygium aromaticum) the bark of $C$. verum against selected bacterial strains in the MIC assay. C. verum have shown antibacterial activity with $2.9 \mathrm{mg} / \mathrm{ml}$ concentration against $S$. typhi G7 Vi-negative and P. fluorescens strains. $P$. 


\section{Indo Global Journal of Pharmaceutical Sciences, 2015; 5(3): 216-224}

fluorescens was found susceptible to $C$. verum essential oil while $E$. coli SS1 and S. aureus were resistant to $C$. verum and $A$. subulatum essential oils, respectively. The GC/MS analysis revealed that essential oils of $C$. cyminum, $C$. verum, A. subulatum, and $S$. aromaticum contain $17.2 \%$ cuminaldehyde, $4.3 \%$ t-cinnamaldehyde, $5.2 \%$ eucalyptol and $0.73 \%$ eugenol, respectively.

The antibacterial activity of methanolic extracts was first performed with $1 \mathrm{mg} / \mathrm{ml}, 5 \mathrm{mg} / \mathrm{ml}$ and $10 \mathrm{mg} / \mathrm{ml}$ concentration of extracts of Dill, Clove and Cinnamon but no activity was obtained in any of the plates. Then the same was repeated with 50 and $100 \mathrm{mg} / \mathrm{ml}$ of extract concentration. The results obtained are tabulated in Table 5. The clove extract showed maximum activity against all the bacterial strains tested except for Pseudomonas while Dill extract showed significant antibacterial activity against gram positive $S$. aureus only. Cinnamon showed mild activity against $B$. subtilis and significant activity against $E$. coli at the concentration of $100 \mathrm{mg} / \mathrm{ml}$. Suree Nanasombat and Pornpan Wimuttigosol [11] have determined the antimicrobial and antioxidant activity of anise, cardamom, cinnamon, dill, mace, zedoary, prikhom and ginger and found that cinnamon oil had highest antibacterial activity (with MIC of $0.5 \mathrm{mg} / \mathrm{ml}$ ) while dill oil showed strong antifungal activity. Javad Aliakbarlu [12] et al. have reported MIC $0.312 \mathrm{mg} / \mathrm{ml}$ against reported bacteria for cinnamon essential oil.

\section{CONCLUSION}

The results obtained lead us to conclusion that Cinnamon oil has excellent antibacterial action among the three essential oils at low concentration (1:3 dilution) while the methanolic extract of clove acts as good antibacterial agent at concentration of $50 \mathrm{mg} / \mathrm{ml}$. Cinnamon oil was found to contain cinnamaldehyde, acetoeugenol, caryophyllene and its oxide as major products which may be responsible for its high activity. Clove methanolic extract contains mainly eugenol and acetoeugenol responsible for its activity. We may utilize less popular cinnamon oil as a good antibacterial agent as emulsion in oil based cosmetic products. Clove oil and extract is known to be used as good antibacterial agent and used in dentistry and other applications. Clove and cinnamon are known to be good antioxidant agents but dill extract has shown mild antioxidant activity. The antioxidant action of eugenol is depicted in the figure 4 given below:

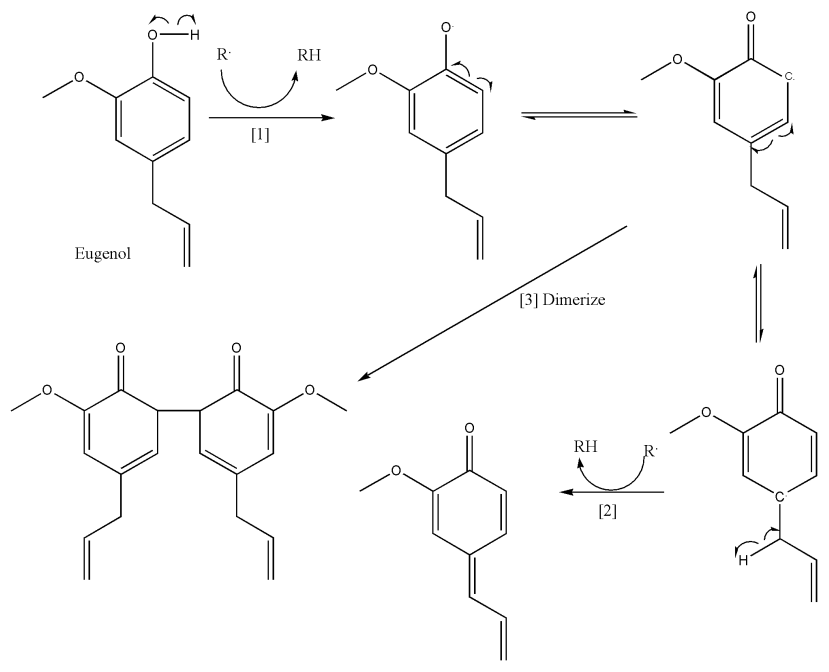

Figure 4: Scheme showing antioxidant potential Eugenol [1] Hydrogen donation to a radical [2] Donation of second hydrogen atom to form more stable quinone structure [3] Dimerization to eugenyl radical

\section{ACKNOWLEDGMENT}

Authors thank to Dr. Sunita Rattan, Additional Director AIAS; Head of Department Dr. Sangeeta Tiwari and the Management of Amity University for providing necessary grant and infrastructure to carry out this work.

\section{REFERENCES}

1. Aromatherapy . Better Health Channel. Retrieved 201408-14.

2. Lawless, Julia (1995). The Illustrated Encyclopedia of Essential Oils: The Complete Guide to the Use of Oils in Aromatherapy and Herbalism; Illustrated Encyclopedia Series; Element, 1995, ISBN 1852307218.

3. "Cloves". American Cancer Society. Retrieved 2012-0506.

4. Retrieved from https://www.organicfacts.net/healthbenefits/essential-oils/health-benefits-of-cinnamonoil.html

5. Retrieved from https://www.organicfacts.net/healthbenefits/essential-oils/dill-essential-oil.html

6. Dupta D.,Girija.Evaluation of InVitro antioxidant and antimicrobial activities of various spices of Indian origin. International Journal of Pharmacy and Pharmaceutical Sciences, 2015; Vol.7, Issue 8, 137-141.

7. Rauf AttiqueBabri, IrshadKhokhar, Zaid Mahmood and Shahid Mahmud. Chemical composition and insecticidal activity of the essential oil of Anethumgraveolens L. Sci.Int.(Lahore), 2012; 24(4),453-455

8. Prashar A, Locke IC, Evans CS. Cytotoxicity of clove (Syzygiumaromaticum) oil and its major components to human skin cells. Cell Prolif. Aug;2006; 39(4):241-8 
Indo Global Journal of Pharmaceutical Sciences, 2015; 5(3): 216-224

9. Chaieb, K., Hajlaoui, H., Zmantar, T., Kahla-Nakbi, A. B., Rouabhia, M., Mahdouani, K. and Bakhrouf, A. The chemical composition and biological activity of clove essential oil, Eugenia caryophyllata (Syzigiumaromaticum L. Myrtaceae): a short review. Phytother. Res.,2007; 21: 501-506. doi: $10.1002 /$ ptr.2124

10. Rasheeha Naveed, Iftikhar Hussain, Abdul Tawab, Muhammad Tariq, Moazur Rahman, Sohail Hameed, M Shahid Mahmood, Abu Baker Siddique and Mazhar Iqbal. Antimicrobial activity of the bioactive components of essential oils from Pakistani spices against Salmonella and other multi-drug resistant bacteria. BMC
Complementary and Alternative Medicine,2013; 13:265274.

11. Suree Nanasombat, Pornpan Wimuttigosol. Antimicrobial and antioxidant activity of spice essential oils. Food Science and Biotechnology, 2011; 20(1):45-53.

12. Javad Aliakbarlu,Surur Khalili Sadaghiani,

Shadieh Mohammadi.Comparative evaluation of antioxidant and anti food-borne bacterial activities of essential oils from some spices commonly consumed in Iran,Food Science and Biotechnology, 2013; 22(6):1487-1493.

Indo Global Journal of Pharmaceutical Sciences( ISSN 22491023 ; CODEN-IGJPAI; NLM ID: 101610675) indexed and abstracted in EMBASE(Elsevier), SCIRUS(Elsevier),CABI, CAB Abstracts, Chemical Abstract Services(CAS), American Chemical Society(ACS), Index Copernicus, EBSCO, DOAJ, Google Scholar and many more. For further details, visit 